Yüzüncü Y1 Üniversitesi
Tarim Bilimleri Dergisi

Araştırma Makalesi (Research Article)

\title{
Ege Bölgesi Bağ Alanlarından Elde Edilen Phomopsis viticola İzolatlarının Morfolojik Moleküler ve Patojenik Karakterizasyonu**
}

\author{
Sahra HOSSEINALIZADEH ${ }^{* 1}$, Ömer ERINCİK², Serap AÇIKGÖZ ${ }^{3}$ \\ 1,2,3 Adnan Menderes Üniversitesi, Ziraat Fakültesi, Bitki Koruma Bölümü, Aydın, Türkiye \\ ${ }^{1} \mathrm{https} / / /$ orcid.org/0000-0002-7491-242X ${ }^{2} \mathrm{https} / / /$ orcid.org/0000-0002-0304-7475 ${ }^{3} \mathrm{https} / / /$ orcid.org/0000-0002-7970-1648 \\ *Sorumlu yazar e-posta: sahraalizadeh88@yahoo.com
}

\section{Makale Bilgileri}

Geliş: 05.08.2020

Kabul: 18.05.2021

Online Yayınlanma 30.06.2021

DOI: $10.29133 /$ yyutbd. 777108

\section{Anahtar kelimeler}

Asma,

Ölükol

Phomopsis viticola,
Öz: Phomopsis viticola'nın neden olduğu Phomopsis sürgün ve yaprak lekesi (Ölükol) dünyada birçok bağ alanında olduğu gibi Türkiye'nin Ege Bölgesinde de sorun olan önemli bir hastalıktır. Bu çalışmada, Ege Bölgesinde bağ alanlarından elde edilen $P$. viticola izolatlarının morfolojik moleküler ve patojenik karakterizasyonu yapılmıştır. Bu amaçla, Ege Bölgesi bağ alanlarından 416 sürgün örneği toplanmış ve toplamda 232 Phomopsis spp. izolatı izole edilmiştir. İzolatların büyük çoğunluğunda (\% 94.39) sadece alfa konidi görülmüşken sadece 13 izolatta alfa ve beta sporları görülmüştür. Fungal izolatların çoğunluğu (\% 69.39) hızlı koloni gelişim göstermişken sınırlı sayıda izolatta (15 adet) yavaş koloni gelişimi gözlemlenmiştir. Fungal izolatların koloni rengi değerlendirmelerinde ise izolatların \% 35.77's1 beyaz, \% 59.05's1 gri ve $\% 5.17$ açık krem renkte koloni oluşturmuştur. $P$. viticola nın moleküler tanımlanması için PCR analizleri yapılmış ve 214 P. viticola izolatın tanısı gerçekleştirilmiştir. Morfolojik olarak PCR negatif ve PCR pozitif izolatların arasında büyük farklılıklara rastlanmamıștır. Bu nedenle $P$. viticola'nın doğru tanılanması için morfolojik tanının yanında moleküler tanının da kullanılması gerekmektedir. Bu çalışmada Ege Bölgesinde bağ alanlarında Ölükol belirtilerini gösteren bitkilerden elde edilen izolatların büyük bir çoğunluğunun (\% 92.24) $P$. viticola olduğu ortaya konmuştur. Patojenisite testinde izolatların farklı virülenslik düzeylerine sahip oldukları $(2.3-18.7 \mathrm{~cm}$ lezyon uzunlukları) görülmüş ancak izolatların morfolojik özellikleri ile virülenslik dereceleri arasında bir ilişsi bulunamamıştır.

\section{Morphologic, Molecular and Pathogenic Characterization of Phomopsis viticola isolates Collected from the Vineyards of the Aegean Region in Turkey}

\section{Article Info}

Received: 05.08 .2020

Accepted: 18.05.2021

Online Published 30.06.2021

DOI: $10.29133 /$ yyutbd.777108

Keywords

Grapevine,

Dead arm

Phomopsis viticola,

\begin{abstract}
Phomopsis cane and leaf spot caused by Phomopsis viticola (dead arm) is an important problem in the vineyards of the Aegean Region of Turkey, like in many parts of the world. In this study, morphological molecular and pathogenic characteristics of $P$. viticola isolates collected from the vineyards of the Aegean Region were determined. For this purpose, 416 shoot samples were collected and a total of 232 Phomopsis spp isolates were isolated. In the majority of isolates (94.39\%), only alpha conidia were observed, while alpha and beta conidia ocured in only 13 isolates. While most of the isolates (69.39\%) showed rapid colony growth, a limited number of isolates (15 izolates) produced slow growing colony. In the fungal colony colour characteristics, $35.77 \%$ of the isolates were white, $59.05 \%$ were gray and $5.17 \%$ were light cream. In the PCR
\end{abstract}


assay, 214 isolates were identified as $P$. viticola. No important differences were found between PCR negative and PCR positive isolates morphologically. Therefore, molecular diagnosis must be made in order to correctly identify $P$. viticola. This study indicated that most of the isolates $(92.24 \%)$ obtained from the plants showing Phomopsis cane and leaf spot symptoms in vineyards of the Aegean Region are $P$. viticola. There were different levels of virulence with the lesion lenght ranging between 2.3 and $18.7 \mathrm{~cm}$ among the isolates tested in pathogenicity test; however, no relationships were observed between any of the morphological and virulence level.

**Çalışma birinci yazarın doktora tezinden üretilmiştir.

\section{Giriş}

Türkiye; toplam 448 bin hektar bağ alanı ile İspanya, Çin, Fransa ve İtalya'dan sonra 5. sırada yer almaktadır (FAO, 2018). Türkiye'nin bağ alanlarının \% 32.5 gibi büyük bir kısmı Ege Bölgesinde bulunmaktadır (Anonim, 2019a). Ülkemiz için önemli olan bağc1lık günümüzde üretimden pazarlamaya kadar geçen süreçte birçok sorunla karşılaşmaktadır. Bu sorunlardan biri de fungal etmenlerin neden olduğu hastalıklardır (Poyraz ve Onoğur, 2011). Bu hastalıklardan birisi dünyada Phomopsis Sürgün ve Yaprak Leke Hastalığı olarak bilinen Phomopsis viticola (Sacc.) Sacc'nın neden olduğu Ölükol hastalı̆̆ıdır (Nita ve ark., 2006). Hastalık ilk olarak ilkbaharda yapraklarda küçük sarı klorotik lekeler şeklinde ortaya çıkmakta, ilerleyen dönemlerde ise sürgünlerin dip kısımlarında koyu renkli lekeler ve odun dokusuna kadar ulaşan çatlaklar oluşturmaktadır (Mostert, 2000). Ölükol Hastalığı ile enfekte olan asmalarda genel olarak yaprak, sürgün hatta salkım kurumaları nedeniyle $\% 10$ civarında verim kaybı meydana gelmekte ve ertesi yıl gözlerinin ölmesi ile de daha yüksek oranlarda verim kayıpları oluşabilmektedir (Anonim, 2019b).

Ülkemizde ilk olarak Karaca ve Eroğlu (1967), tarafindan 1967 yılında Marmara ve Ege Bölgelerinde rapor edilmiş bu hastalık, o dönemde dünyada kabul gören ismi olan Ölükol (Dead-Arm) ile adlandırılmıştır. Daha sonraki yıllarda dünyada hastalığın ismi Phomopsis Sürgün ve Yaprak Leke hastalığı olarak değiştirilse de Türkiye'de Ölükol isminin kullanımına devam edilmiş̧tir. Hastalığın etmeni doğada anamorf formda bulunan fungal patojen $P$. viticola olarak bildirilmiştir. Gerek Phomopsis cinsinde yer alan patojenlerin karmaşık konukçu dizileri gerekse de DNA dizilim analizleri sonucunda etmenin birden fazla teleomorf Diaporthe türü ile ilişkilendirilmiş olması nedeniyle hastalığın etmeni olarak anamorf $P$. viticola'nın kullanımı yaygınlıkla devam etmektedir (Niekerk ve ark., 2005).

Ülkemizde Ege ve Marmara bölgeleri bağ alanlarında Phomopsis sürgün ve yaprak leke belirtilerini gösteren asmalardan sıklıkla $P$. viticola'nın izole edildiği birçok araştırıcı tarafından bildirilmiştir (Çetinkaya ve Onoğur, 2006; Yıldırım, 2014; Awan, 2017; Güngör Savaş, 2019). Bunun dışında Ankara ili bağ alanlarında Ölükol Hastalığının belirtilerini sergileyen asma örnekleri üzerinde morfolojik tanı esas alınarak P. viticola'nın varlığı bildirilmiştir (Özben, 2011). Ege Bölgesinde sınırlı sayıda alandan asma sürgün örneklerinden toplanan 23 fungal izolatın morfolojik karakterizasyonunun yanısıra ve DNA dizilimi ile moleküler olarak tanısı yapılmış ve tüm izolatlar $P$. viticola (Diaporthe ampelina) olarak tanılanmıştır (Awan, 2017). Manisa ve Tekirdağ illerinden $P$. viticola etmenini morfolojik yapılarına bakılarak ve Real Time (RT)-PCR'dan elde edilen PCR ürünlerin DNA dizilimi çıkartılarak P. viticola'nın tanısı yapılmıştır (Güngör Savaş, 2019). Hosseinalizadeh ve ark. (2020), Ege Bölgesinin İzmir ve Manisa illerinden $P$. viticola belirtilerini sergileyen asmalardan morfolojik özeliklerine bakılarak toplam 80 izolatta $P$. viticola etmenini tespit etmişlerdir. Ancak son y1llarda asmada diğer Phomopsis türlerinin yanısıra odun dokusunda farklı patojenlerin de varlığ bildirilmeye başlanmış olup bu patojenlerin birbirlerine benzer şekilde belirtiler meydana getirebildikleri ve hatta birlikte karışık enfeksiyonların ise hastalıkların tanısını daha karmaşık hale getirdiği belirtilmektedir (Merrin ve ark., 1995; Mostert ve ark., 2001; Niekerk ve ark., 2005; Udayanga ve ark., 2011; Schilder, 2005; Güngör Savaş, 2019). Böyle durumlarda etmenlerin hızlı ve güvenilir tanısı ön plana çımaktadır. Morfolojik tanının bazı durumlarda etmenlerin teşhisinde tek başına yeterli olmaması, araştırıcıları moleküler düzeyde tanıya yönlendirmiştir. Nitekim son zamanlarda geliştirilmiş ticari bir kit (Phomopsis viticola End-Point PCR Kit-NORGEN, BIOTEK CORPORATION/ Canada) ile $P$. viticola'nın PCR ile tanısı yapılabilir hale gelmiştir. Ege Bölgesi bağ alanlarında Ölükol çalışmalarına 
bakıldığında genelde İzmir ve Manisa ilerinden toplanan sınırlı sayıda örnekler üzerinde çalışmalar yapıldığg görülmektedir.

Bu çalışmada Ege Bölgesinde önemli bağ üreticisi illeri olan Aydın, Denizli, Manisa ve İzmir'de Ölükol belirtisi gösteren bitki örnekleri $P$. viticola yönünden incelenmiştir. Bitki örneklerinden elde edilen izolatların önce morfolojik karakterizasyonu yapılmış ardından $P$. viticola'ya özgü ticari bir tanı kiti ile PCR da moleküler tanıları gerçekleştirilmiştir. Bunun dışında, seçilmiş bazı $P$. viticola izolatlarının sürgün testi ile virülenslik belirlenme çalışmaları yürütülmüştür.

\section{Materyal ve Yöntem}

\subsection{Hastalıklı bitkilerin toplanması}

Ege Bölgesinin asma üretimi yapılan Denizli (Çal, Buldan ve Güney), İzmir (Menemen, Kemalpaşa ve Bayındır ), Manisa (Alaşehir, Salihli ve Saruhanlı) ve Aydın (Koçarlı, Nazili ve Kuşadası) illerinden Ölükol Hastalık etmeni $P$. viticola izolatlarının elde edilmesi için 2018 yılının üretim sezonu içerisinde sörvey çalışmaları yapılmıştır. Bu çalışmalar sırasında omcaların sürgünlerinde siyah lekeler, çatlamış kabuk dokuları ve yapraklarda sarı küçük lokal lekeler gibi, Ölükol Hastalığı belirtileri gösteren bitkilerin sürgünlerinin dip kısımlarından 5-10 cm uzunluğunda olacak şekilde toplam 416 adet sürgün örneği alınmıştır (Çizelge 1).

\subsection{Sürgün örneklerinin izolasyonu ve saflaştırması}

Laboratuvara getirilen sürgün örneklerinin Ölükol Hastalığı belirtisi gösteren kısımlarından steril bistüri yardımıyla hasta ve sağlıklı dokuyu içerecek $5 \times 6 \mathrm{~mm}$ boyutlarında parçalar kesilmiş ve $\% 2$ 'lik $\mathrm{NaOCl}$ içinde 2 dakika süre ile bekletilerek yüzeysel olarak dezenfekte edilmiştir. Steril saf suda 2 kez durulanıp takiben steril filitre kağıtları arasında kurutulan örnekler petri kaplarında bulunan patates dekstroz agar (PDA, Difco ${ }^{\mathrm{TM}}$ Becton Dichson, USA) üzerine yerleştirilerek karanlık koşullarda $24^{\circ} \mathrm{C}$ de inkübe edilmişlerdir. Yaklaşık bir haftalık inkubasyonun ardından gelişen koloniler makroskobik ve mikroskobik olarak incelenmiş ve $P$. viticola olduğu düşünülen kolonilerin kenarındaki misel uçlarından alınan parçalar tekrar PDA besi yerine alınarak saf kültürler elde edilmiştir.

\subsection{Fungal izolatların kültürel özelliklerinin değerlendirilmesi}

Saflaştırılan tüm izolatlar PDA besi ortamında geliştirilerek kültürel özellikleri yönünden incelenmişlerdir (Schilder ve ark., 2005). Bunun için; PDA üzerinde aktif olarak gelişen her bir izolata ait kolonilerin kenar kısımlarından alınan $4 \mathrm{~mm}$ çapındaki diskler, içinde PDA bulunan $9 \mathrm{~cm}$ 'lik Petri kabının orta kısmına yerleştirilmiş ve izolatlar inkübatörde $24^{\circ} \mathrm{C}$ de 7 gün karanlık koşulları takiben 7 gün aydınlık ortamda inkübasyona bırakılmışlardır. Her bir Petri bir tekerrür olarak değerlendirerek çalışma üç tekerrürlü olarak yapıılmıştır.

\subsubsection{Koloni gelişme hızları ve piknit oluşumu}

İnkübasyonun 14. gününde toplam 232 adet izolatın koloni gelişme hızları koloni çapları birbirini dik kesen iki noktadan cetvelle ölçülerek belirlenmiştir. Her bir izolat için koloni çapı ortalaması hesaplanmış ve bu değerlere göre izolatlar gruplandırılmıştır. Gelişim hızı yönünden; yavaş (Grup 1), orta (Grup II), ve yüksek (Grup III) olacak şekilde üç grup, çalışmada elde edilen en büyük koloni ile en küçük koloni farkının üç eşit aralığa bölünmesi ile oluşturulmuştur (Erincik ve ark., 2018). İzolatların piknit oluşumu ise inkübasyonun 4. haftasında değerlendirilmiştir. Yapılan değerlendirmelerde her bir Petri kabının tesadüfi olarak seçilen yaklaşık $1 \mathrm{~cm}^{2}$ 'lik dört farklı alanında piknit yoğunluğu belirlenmiştir. Koloni üzerinde ölçüm yapılacak alan $4 \mathrm{~mm}$ çapında bir mantar delici ile kesilerek işaretlenmiştir. Stereomikroskop altında kesili alanda 0-4 (0: piknit yok, 1: piknit sayısı 125, 2: piknit sayıs1 26-50, 3: piknit sayıs1 50-100 ve 4: piknit sayıs1 >100) skala kullanılarak piknit sayıs1 tahmin edilmiştir. 


\subsubsection{Koloni renkleri ve spor oluşumları}

İzolatların 14. gününde koloniler renk tipleri ( $\mathrm{W}$, beyaz renkli koloni, $\mathrm{G}$, gri renkli koloni ve kahve renkli koloni ) yönünden değerlendirilmiştir. İnkübasyonun dördüncü haftasında 3 tekerrüründen tesadüf olarak bir Petri kabı seçilmiş ve tüm izolatlarda 25 adet alfa $(\alpha)$ konidi , bulunması durumunda ise 25 adet beta ( $\beta$ ) konidi'nin boyutları mikroskop (Leica DFC320) altında Labsens bilgisayar programı kullanılarak ölçülmüştür (Uecker, 1998; Kanematsu ve ark., 2000).

\subsection{Fungal izolatlarının PCR da moleküler tanılanması}

DNA izolasyon için kullanılacak izolatlara ait miseller, PDA ortamı üzerine konulan steril selefon diskler üzerinde yerleştirilmiş ve inkübatörde $24^{\circ} \mathrm{C}$ 'de karanlık koşullarda 6-7 gün inkübasyonun bırakılmıştır. Selefon disklerde gelişen kolonilerden, yaklaşık $3 \times 3 \mathrm{~cm}$ boyutlarında misel kitlesi steril kürdan ile alınarak $1.5 \mathrm{ml}$ santrifüj tüplere yerleştirilmiş ve ardından DNA ekstraksiyonu Erincik ve ark, (2011)' e göre yapılmıştır. Elde edilen DNA'lar agarose jelde DNA'nın varlığına bakılmıştır ve DNA'lar PCR da kullanılmak üzere $-20^{\circ} \mathrm{C}$ de saklanmıştır.

Elde edilen DNA'ların PCR için Phomopsis viticola End-Point PCR Kiti kullanılmıştır. Kit protokolüne göre; $10 \mu \mathrm{L}$ MDx 2X PCR Master Mix, $2 \mu \mathrm{L}$ P. viticola Primer Mix, $2.5 \mu 1$ örnek DNA ve $5.5 \mu 1$ steril saf ile toplam $20 \mu$ l'ye tamamlanmıştır. Thermal cycler içerisinde 40 döngü olarak planlanan PCR da ilk denatürasyon $94^{\circ} \mathrm{C}$ de 3 dakika olarak başlanmış ve $94^{\circ} \mathrm{C}$ de 15 saniye denatürasyon, $60^{\circ} \mathrm{C}$ de 30 saniye annealing, $72^{\circ} \mathrm{C}$ de 45 saniye extension ve $72^{\circ} \mathrm{C}$ de 5 dakika final extension şeklinde uygulanmıştır. PCR ürünleri $150 \mathrm{~V}, 30$ dakika \% 1.4 lik agaroz jel eletroforezde ayrıştırılacak ve görüntülenmiştir. Moleküler ağırlık olarak 2000 bp DNA marker kullanılmış ve $P$. viticola' nın tanısı 300 bp ağırlıklar esas alınarak yapılmıştır. Ayrıca kitin içerisinde bulunan $P$. viticola negatif ve pozitif örnekler PCR da kullanılmıştır (Phomopsis viticola End-Point PCR Kit, NORGEN, BIOTEK CORPORATION, Canada).

\subsection{Fungal izolatların virülenslik testi}

PCR testi ile $P$. viticola olduğu teyit edilmiş izolatlar arasından, kültürel özellikleri göz önünde bulundurularak tüm illeri temsil edecek şekilde toplam 49 adet izolat virülenslik testi için seçilmiştir. Virülenslik testi, sultani çekirdeksiz asmalardan alınan 1-2 cm çapında ve yaklaşık $30 \mathrm{~cm}$ boyundaki homojen görünümlü yeşil asma sürgünleri üzerinde Rawnsley (2002)'e göre yapılmıştır. Test için öncelikle sürgünler musluk suyuyla yıkanıp kurulandıktan sonra \% 2'lik sodyum hipoklorit içerisinde 2 dakika bekletilerek yüzeysel olarak sterilize edilmiş ve steril su ile durulanıp, steril koşullarda kurumaları sağlanmıştır. Daha sonra her bir dal parçasının üst uç kısmı eriyik haldeki parafine daldırılarak yara bölgesinin kapanması sağlanmış ve sürgünlerin uç kısmın $10 \mathrm{~cm}$ altından $4 \mathrm{~mm}$ çapındaki mantar delici ile birer disk çıkartılarak yara açılmış, ardından PDA üzerinde geliştirilen izolatların kolonilerinin genç kısımlarından alınan aynı çaptaki miselyal diskler yaranın içine gelecek şekilde yerleştirilerek inokulasyon işlemi gerçekleştirilmiştir. Miselyal diskin kurumasını engellemek için inokulasyon yerleri parafilm ile sarılmıştır. Kontrol için kullanılan sürgünlerde sadece steril PDA diski konulmuştur. Dallar dik bir şekilde, içerisinde nemli steril perlit bulunan saksılara çelik köklendirme yöntemine benzer şekilde daldırılmış iklim odasında $25^{\circ} \mathrm{C}$ sıcaklıkta 30 gün süre ile karanlıkta inkübe edilmişlerdir. Her tekerrürde tek dal olacak şekilde deneme dört tekerrürlü olarak yürütülmüştür. İnokulasyondan 1 ay sonra sürgünler üzerinde oluşan lezyonlar uzunlamasına bir uçtan diğer uca ölçülmüştür. Elde edilen değerden yara alanının uzunluğu çıkarılarak gerçek lezyon uzunluğu elde edilmiştir. Verilerin istatiksel analizi tek yönlü varyans analizi ile $(p$ değeri $<0,05)$ SPSS 18.0 program paketinde yapılmış ve izolatlar arasındaki virülenslik farklılıkları Duncan Çoklu Karşılaştırma testine göre belirlenmiştir. 


\section{Bulgular}

\section{1. Örnekleme ve izolasyon}

Ege Bölgesinin Denizli (Çal, Buldan ve Güney), İzmir (Menemen, Kemalpaşa ve Bayındır ), Manisa (Alaşehir, Salihli ve Saruhanlı) ve Aydın (Koçarlı, Nazili ve Kuşadası) illerinin bağ alanlarında Ölükol Hastalığının belirtileri olan asma sürgün diplerinde siyah lekeler ile çatlamış kabuk dokuları ve yapraklarda sarı küçük lokal lekelere sıklıkla gözlemlenmiştir (Şekil 1). Örnekleme çalışmaları yapılan tüm il ve ilçelerde ölü kol hastalığı belirtisi gösteren asmalara rastlanmış ve toplamda 416 adet sürgün örneği alınmıştır. Laboratuvara getirilen örneklerden PDA besi ortamında patojenin izolasyon işlemleri gerçekleştirilmiştir. İzolasyon Petrilerinde görsel olarak belirgin hale gelen miselyal koloniler makroskobik ve mikroskobik olarak incelenmiş ve sonuçta Aydın'dan 53, Denizli'den 50, Manisa'dan 59 ve İzmir' den 70 olmak üzere $P$. viticola olduğu düşünülen toplam 232 adet izolat saflaştırılmıştır (Çizelge 1).

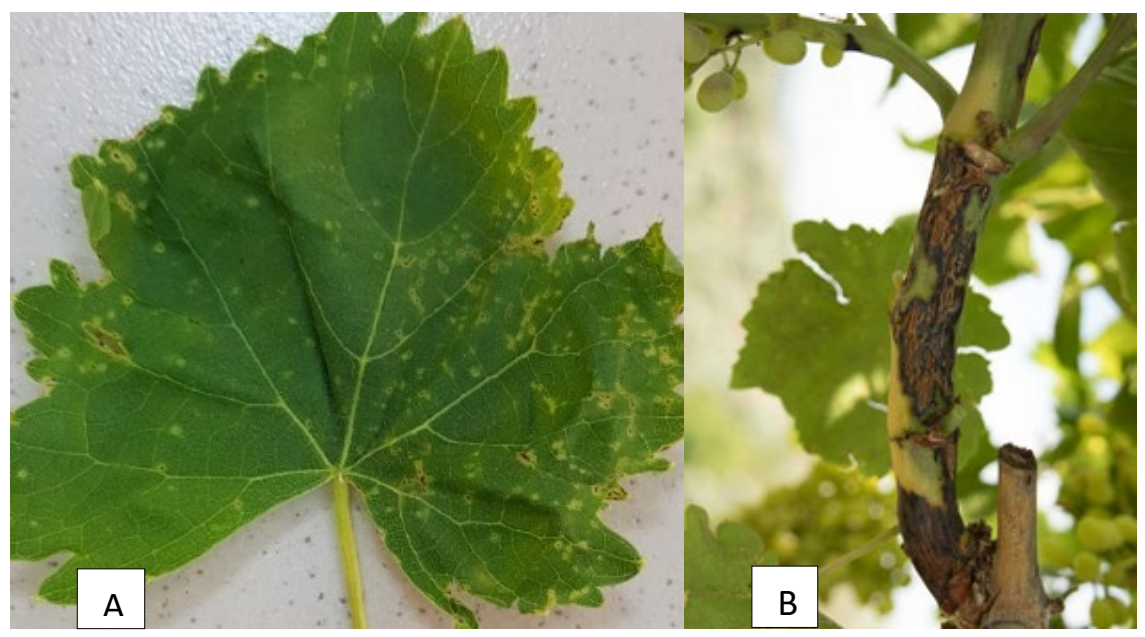

Şekil 1. Sörveylerde örnekleme yapılan yapılan bitkilerde Ölü kol belirtileri: Asma yapraklarda sarı klorotik lekeler (A) ve sürgünlerde siyah lezyonlar (B).

Çizelge 1. Ölükol belirtisi gösteren bitkilerden alınan örnek sayıları ve izole edilen Phomopsis spp. izolat sayılarının Ege Bölgesi il ve ilçelerine göre dağılımı

\begin{tabular}{|c|c|c|c|}
\hline İller & İlçeler & Örnek sayıları & İzolat sayıları \\
\hline \multirow{4}{*}{ Aydin } & Nazili & 32 & 18 \\
\hline & Koçarlı & 11 & 8 \\
\hline & Söke & 5 & 4 \\
\hline & Kuşadası & 42 & 23 \\
\hline \multirow{4}{*}{ Denizli } & & 90 & 53 \\
\hline & Çal & 20 & 17 \\
\hline & Güney & 9 & 6 \\
\hline & Buldan & 33 & 27 \\
\hline \multicolumn{2}{|c|}{ Ara Toplam } & 62 & 50 \\
\hline \multirow{3}{*}{ Manisa } & Salihli & 43 & 24 \\
\hline & Alaşehir & 24 & 13 \\
\hline & Saruhanlı & 34 & 22 \\
\hline \multirow{7}{*}{ İzmir } & & 99 & 59 \\
\hline & Selçuk & 30 & 15 \\
\hline & Bayındır & 53 & 25 \\
\hline & Efem çukur & 4 & 3 \\
\hline & Urla & 8 & 3 \\
\hline & Menemen & 49 & 15 \\
\hline & Kemal paşa & 21 & 9 \\
\hline \multicolumn{2}{|c|}{ Ara Toplam } & 165 & 70 \\
\hline \multicolumn{2}{|c|}{ Genel Toplam } & 416 & 232 \\
\hline
\end{tabular}




\subsection{Fungal izolatların tanılanması ve kültürel özelikleri}

\subsubsection{Koloni gelişme hızları ve piknit oluşumu}

İzolatlar, PDA ortamında $24^{\circ} \mathrm{C}^{\prime}$ de 14 günlük inkübasyon sonrasında farklı miselyal koloni gelişimleri göstermişlerdir. Toplam 15 izolat $2.28-3.85 \mathrm{~cm}$ ortalama miselyal çapı ile yavaş gelişen Grup 1 'de yer almıştır. Ortalama miselyal koloni çapı $3.86-5.43 \mathrm{~cm}$ olan 56 izolat orta hızda gelişen Grup 2'de yer almıştır. Geri kalan 161 izolat 5.44-7 cm ortalama miselyal koloni çapı ile hızlı gelişen Grup 3 'de yer almıştır (Çizelge 2). Tüm illerde orta ve hızlı gelişen izolatlara rastlanmışken Denizli ilinden yavaş gelişen izolatlara rastlanmamıştır.

İnkübasyonun 4. haftasında izolatlara ait piknit sayısı ortalama skala değerlerine göre, 5 izolatta piknit oluşumu gözlenmemiştir. Beş izolat "1" skala değerini alarak düşük sayıda piknit $\left(1-25 / \mathrm{cm}^{2}\right)$ oluşturmuştur. Kalan izolatlardan, 31'i " 2 " skala değerini alarak orta düşük sayıda piknit $\left(26-50 / \mathrm{cm}^{2}\right)$, 151 'i " 3 " skala değerini alarak orta yüksek sayıda piknit $\left(50-100 / \mathrm{cm}^{2}\right)$ ve 40 '1 "4" skala değerini alarak yüksek sayıda piknit (>100) oluşturduğu saptanmıştır (Şekil 2 ve Çizelge 2).
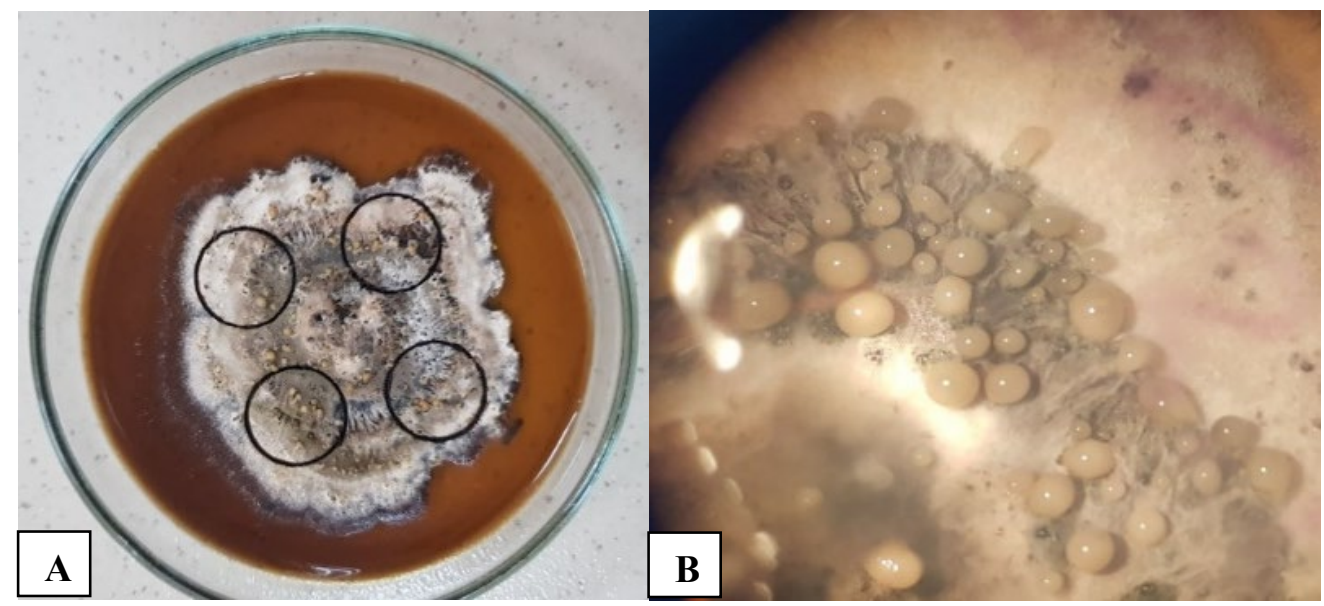

Şekil 2. İnkübasyonun 4. haftasında piknit yoğunluğu belirlemede sayım yapılan alanlar (A) ve stereomikroskop altında piknit görünümü (B).

\subsubsection{Koloni renkleri ve spor oluşumları}

PDA'da $24^{\circ} \mathrm{C} 14$ günlük inkübasyonun ardından, izolatlar koloni renkleri yönünden beyaz, gri ve açık krem olmak üzere 3 farklı gruba ayrılmışlardır. Toplam 137 izolat gri, 83 izolat beyaz ve 12 izolat açık krem koloniler oluşturmuştur (Şekil 3). Beyaz ve gri renkli izolatlara tüm illerde rastlanırken Manisa'da krem renkli izolata rastlanmamıştır. (Çizelge 2).
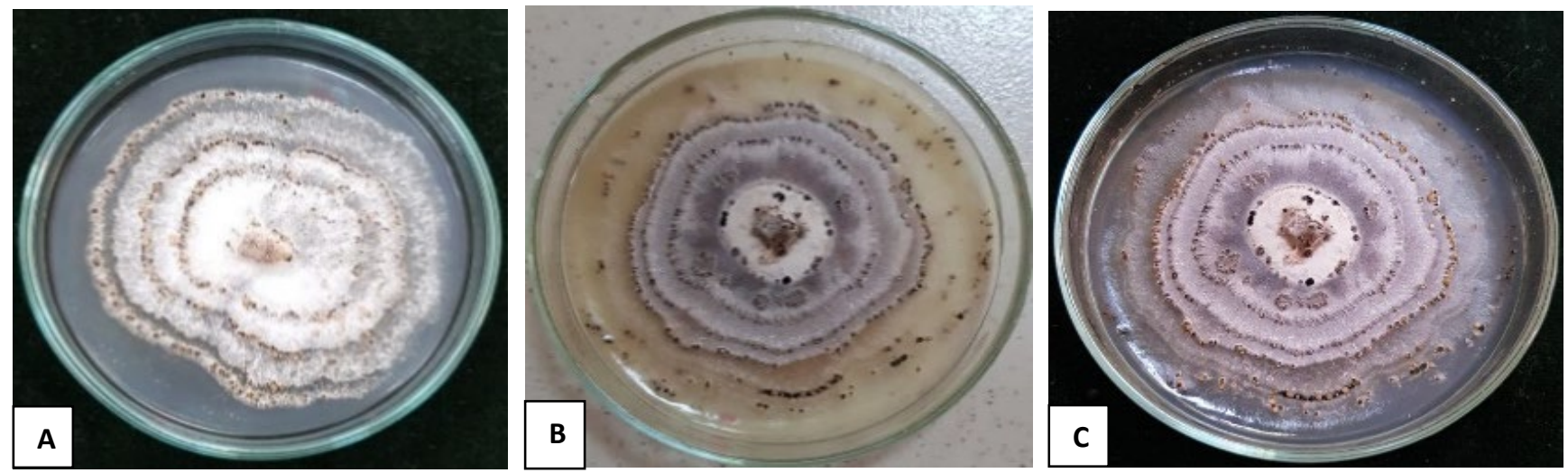

Şekil 3. İnkübasyonun 14. gününde beyaz (A), gri (B), açık krem (C ) renkte oluşan Phomopsis spp. Kolonileri. 
Çizelge 2. Ege Bölgesin'den elde edilen Phomopsis spp. izolatlarının patates dekstroz agar besi ortamında 14 günlük miselyal koloni çapları, koloni renkleri ve inkübasyonun 4 . haftasında piknit oluşumuna göre iller bazında sayısal dağılımları

\begin{tabular}{|c|c|c|c|c|c|c|c|c|c|c|c|}
\hline \multirow[t]{2}{*}{ İller } & \multicolumn{3}{|c|}{$\begin{array}{c}\text { Koni Çap Aralığ }{ }^{\prime}(\mathrm{cm}) \text { ve İzolat } \\
\text { Sayıları }^{a}\end{array}$} & \multicolumn{3}{|c|}{ Koloni Renkleri } & \multicolumn{5}{|c|}{ Stroma Oluşumu İndex Değerib } \\
\hline & Grup I & Grup II & Grup II & Beyaz & Gri & Krem & 0 & 1 & 2 & 3 & 4 \\
\hline Aydın & $\begin{array}{c}1 \\
(0.44)^{\mathrm{c}}\end{array}$ & $\begin{array}{c}11 \\
(4.75)\end{array}$ & $\begin{array}{c}41 \\
(17.67)\end{array}$ & $23(9.92)$ & $\begin{array}{c}28 \\
(12.06)\end{array}$ & $\begin{array}{c}2 \\
(0.86)\end{array}$ & 0 & $\begin{array}{c}1 \\
(0.43)\end{array}$ & $4(1.72)$ & $\begin{array}{c}30 \\
(12.93)\end{array}$ & $18(7.76)$ \\
\hline Denizli & 0 & $8(3.45)$ & $\begin{array}{c}42 \\
(18.10)\end{array}$ & $13(5.6)$ & $\begin{array}{c}33 \\
(14.23)\end{array}$ & $\begin{array}{c}4 \\
(1.72)\end{array}$ & 0 & $\begin{array}{c}1 \\
(0.43)\end{array}$ & $8(3.45)$ & $29(12.5)$ & $12(5.17)$ \\
\hline Manisa & $\begin{array}{c}6 \\
(2.56)\end{array}$ & $\begin{array}{c}15 \\
(6.47)\end{array}$ & $\begin{array}{c}38 \\
(16.38)\end{array}$ & $16(6.89)$ & $\begin{array}{c}43 \\
(18.53)\end{array}$ & 0 & $\begin{array}{c}3 \\
(1.30)\end{array}$ & $\begin{array}{c}1 \\
(0.43)\end{array}$ & $4(1.72)$ & $\begin{array}{c}45 \\
(19.40)\end{array}$ & $6(2.59)$ \\
\hline İzmir & $\begin{array}{c}8 \\
(3.45)\end{array}$ & $\begin{array}{c}22 \\
(9.49)\end{array}$ & $\begin{array}{c}40 \\
(17.24)\end{array}$ & $\begin{array}{c}31 \\
(13.36)\end{array}$ & $\begin{array}{c}33 \\
(14.23) \\
\end{array}$ & $\begin{array}{c}6 \\
(2.59)\end{array}$ & $\begin{array}{c}2 \\
(0.86)\end{array}$ & $\begin{array}{c}2 \\
(0.86)\end{array}$ & $15(6.47)$ & $\begin{array}{c}47 \\
(20.26) \\
\end{array}$ & $4(1.72)$ \\
\hline
\end{tabular}

a: Koni Çap Aralığı (cm): Grup I (2.28-3.85), Grup II (3.86-5.43) ve Grup III (5.44-7).

b: 0-4 skalası (1 cm2'lik alanda piknit sayıs1); 0 (piknit yok), 1 (1-25), 2 (26.50), $3(50-100)$ ve $4(100<)$.

c: Parantez içerisinde yer alan değerler izolatların \% değerini göstermektedir.

İnkübasyonun 14. gününde izolatların spor değerlendirilmesinde; izolatların hepsi PDA üzerinde $\alpha$ sporları üretmiş ve sadece 13 izolatta $\beta$ sporları görülmüş ve $\alpha$ sporların yoğunluğu $\beta$ sporlarına göre daha fazla olduğu gözlemlenmiştir. $\alpha$ sporların boyutları ortalama 8-11.04 $\mu \mathrm{m} \times 1.7-2.8$ $\mu \mathrm{m}$ büyüklük arasında değişmiştir. $\beta$ sporlar ise 20.5-25.14 $\mu \mathrm{m} \times 0.83-1.06 \mu \mathrm{m}$ boyutlarında olup kıvrımlı uçlar oluşturmuşlardır (Şekil 4). Toplam Aydın'da 4, Denizli'de 1, Manisa'da 3 ve İzmir'de 5 izolatta her iki spor ( $\alpha$ ve $\beta$ ) tipi görünürken ve diğer izolatlarda (219 izolat) sadece $\alpha$ sporların varlığ1 belirlenmiştir.
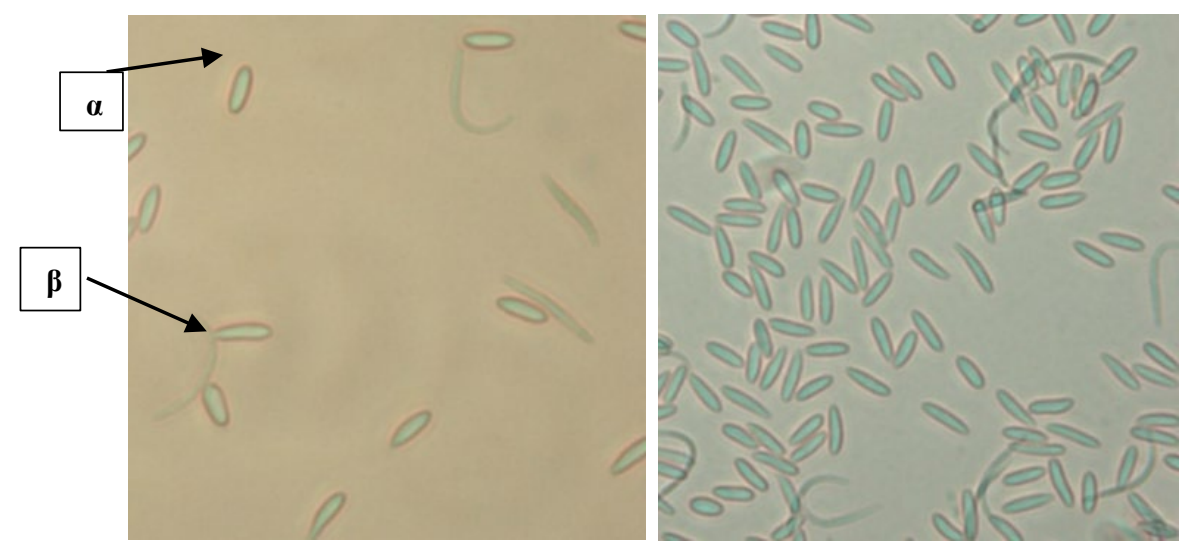

Şekil 4. Fungal izolatların $\alpha$ ve $\beta$ sporlarından görünümler.

\subsection{Fungal izolatlarının tanılanması}

Ticari kit ile yapılan PCR testi sonucunda 232 izolattan 214'ünde beklenen 300 bp ağırlığında bandlar elde edilmiştir (Şekil 5 ve Çizelge 3). Böylece bu izolatların P. viticola olarak kesin tanısı gerçekleştirilmiştir. Örnekleme yapılan tüm illerde $P$. viticola izolatları elde edilmiştir. Çizelge 8'e göre Aydın ilinden 50, Denizli ilinden 50, Manisa ilinden 52 ve İzmir ilinden 62 izolat $P$. viticola izolatı olarak tanılanmıştır. 


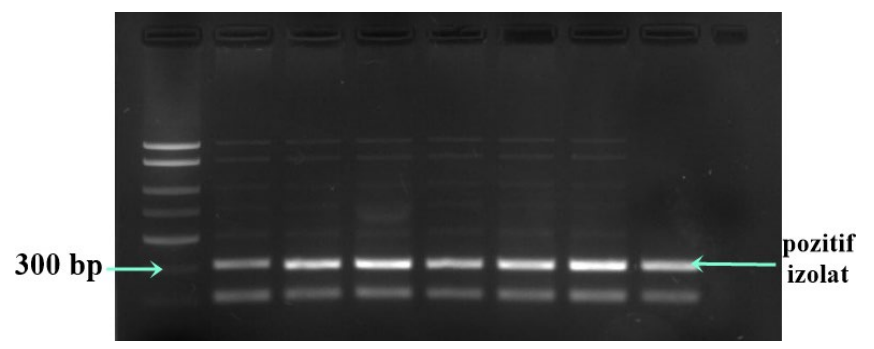

Şekil 5. Phomopsis viticola izolatlarının PCR ürünlerine ait elektroforetik görünümü.

Çizelge 3. PCR testi sonucunda tanılanan Phomopsis viticola izolat sayılarının il ve ilçelerine göre dağılımı

\begin{tabular}{c|c|c}
\hline İller & İlçeler & İzolat sayları \\
\hline \multirow{2}{*}{ Aydın } & Nazili & 18 \\
& Koçarlı & 6 \\
& Söke & 2 \\
& Kuşadası & 24 \\
& Ara Toplam & 50 \\
\hline \multirow{2}{*}{ Denizli } & Çal & 15 \\
& Günay & 6 \\
& Buldan & 29 \\
\hline \multirow{2}{*}{ Manisa } & Ara Toplam & 50 \\
& Salihli & 24 \\
& Alaşehir & 12 \\
& Saruhanlı & 16 \\
& Ara Toplam & 52 \\
\hline \multirow{2}{*}{ İzmir } & Selçuk & 13 \\
& Bayındır & 26 \\
& Efem çukur & 1 \\
& Urla & 1 \\
& Menemen & 14 \\
& Kemal paşa & 7 \\
\hline Genel Toplam & Ara Toplam & 62 \\
\hline
\end{tabular}

\section{5. İzolatların virülenslikleri}

Virülenslik testinde tüm izolatlar asma sürgünlerinde siyahımsı kahverengi nekrotik yüzeysel lezyonlar meydana getirmiştir (Şekil 4). Kontrol sürgünlerinde ise nekrotik lezyon oluşmamıştır. İzolatlara göre sürgünlerde gelişen lezyonların uzunluk ortalamas $12.3-18.7 \mathrm{~cm}$ arasında değişmiş olup, bunlardan bazıları arasındaki fark istatistiki olarak önemli bulunmuştur (Çizelge 4). En virülent izolat, 18.7 cm'lik ortalama lezyon uzunluğu ile İzmir'in Bayındır ilçesinden elde edilmiş olan ve kültürde beyaz koloni oluşturup hızlı gelişme özelliğine sahip 1061B izolatı olmuştur. Bunu $15.3 \mathrm{~cm}$ lezyon uzunluğu ile Manisa ilinin Saruhanlı ilçesinden toplanmış kültürde gri koloni oluşturup orta hızda gelişen 998Sr izolatı takip etmiştir. Farklı illerden toplanmış ve aralarında kültürde gri ve beyaz koloni ile yavaş, orta hızda ve hızlı gelişen özellikte izolatların olduğu 14 izolat $3 \mathrm{~cm}$ ve altında lezyon meydana getirerek düşük virülenslik göstermişlerdir. İzolatların büyük bir çoğunluğu (28 izolat) $3.1-6.5 \mathrm{~cm}$ lezyon aralığında yer alarak düşük orta virülenslik derecesi göstermişlerdir. Geri kalan 5 izolat ise 7.8$11.6 \mathrm{~cm}$ lezyon aralığı ile yüksek orta virülent grubunda yer almıştır. Yine izolatların piknit oluşturma potansiyelinin virülenslikte belirleyici bir özellik olmadığı görülmektedir. Örneğin 4 skala değerini alan izolatlardan $799 \mathrm{Se}, 812 \mathrm{Ku}$ ve $783 \mathrm{Se}$ sirasiyla $2.4,3.1$ ve $4.1 \mathrm{~cm}$ uzunluğunda lezyonlar meydana getirirken en yüksek virülensliğe sahip 1061B $(18.7 \mathrm{~cm})$ ve $998 \mathrm{Sr}(15.3 \mathrm{~cm})$ izolatları ile en düşük virülensliğe sahip $847 \mathrm{Ku}(2.3 \mathrm{~cm})$ izolatı 3 nolu piktit oluşum skalasında yer almıştır. Tüm izolatların $\alpha$ konidi şekil ve büyüklük olarak birbirlerine benzer bulunmuşlardır. Sadece 6 izolatta $\beta$ konidi bulunmuş ve bunlar virülenslik, koloni gelişimi ve rengi ile piknit oluşumu yönünden diğerlerine göre belirgin bir farklılık göstermemişlerdir. Genel olarak morfolojik özellikler (koloni rengi, gelişme hızı, piknit oluşturma ve spor büyüklükleri) ile virülenslik arasında belirgin bir ilişki bulunmamıştır. 
Çizelge 4. Phomopsis viticola izolatlarının asma sürgününde oluşturduğu lezyonların büyüklükleri ve izolatların patates dekstroz agar besi ortamında kültürel özelikleri

\begin{tabular}{|c|c|c|c|c|c|c|c|c|}
\hline \multirow[t]{2}{*}{ İzolat } & \multirow[t]{2}{*}{ Lezyon Uzunluğu(cm) ${ }^{\mathrm{a}}$} & \multirow[t]{2}{*}{$\begin{array}{c}\text { Koloni } \\
\text { gelişim hızı }\end{array}$} & \multirow[t]{2}{*}{$\begin{array}{l}\text { Piknit skala } \\
\text { değeri }\end{array}$} & \multirow[t]{2}{*}{$\begin{array}{l}\text { Koloni } \\
\text { rengi }\end{array}$} & \multicolumn{2}{|c|}{ Alfa Spor Boyut } & \multicolumn{2}{|c|}{$\begin{array}{l}\text { Beta Sporların } \\
\text { ölçümü }\end{array}$} \\
\hline & & & & & $\begin{array}{l}\text { Boy } \\
(\mu \mathrm{m})\end{array}$ & $\begin{array}{c}\text { En } \\
(\mu \mathrm{m})\end{array}$ & $\begin{array}{l}\text { Boy } \\
(\mu \mathrm{m})\end{array}$ & $\begin{array}{c}\text { En } \\
(\mu \mathrm{m})\end{array}$ \\
\hline $847 \mathrm{Ku}$ & $2.3 \mathrm{~h}^{\mathrm{b}}$ & III & 3 & Gri & 9.9 & 2.68 & - & - \\
\hline 799Se & $2.4 \mathrm{gh}$ & III & 4 & Beyaz & 9.11 & 2.27 & - & - \\
\hline $910 \mathrm{M}$ & $2.5 \mathrm{gh}$ & I & 3 & Beyaz & 9.46 & 1.8 & 22.11 & 0.89 \\
\hline $1032 \mathrm{~K}$ & $2.5 \mathrm{gh}$ & III & 2 & Gri & 9.62 & 1.73 & - & - \\
\hline 1098B & $2.6 \mathrm{gh}$ & III & 3 & Gri & 9.1 & 2.41 & - & - \\
\hline $889 \mathrm{G}$ & $2.6 \mathrm{gh}$ & II & 2 & Gri & 9.54 & 2.45 & - & - \\
\hline $843 \mathrm{Ku}$ & $2.6 \mathrm{gh}$ & II & 3 & Gri & 9.6 & 2.32 & - & - \\
\hline $1124 \mathrm{Sa}$ & $2.7 \mathrm{gh}$ & II & 2 & Beyaz & 8.23 & 1.72 & 20.5 & 0.89 \\
\hline 1080B & $2.9 \mathrm{gh}$ & II & 2 & Gri & 9.35 & 1.86 & - & - \\
\hline $809 \mathrm{Ku}$ & $2.9 \mathrm{gh}$ & II & 3 & Gri & 7.73 & 2.18 & - & - \\
\hline $759 \mathrm{Ko}$ & $2.9 \mathrm{gh}$ & III & 3 & Gri & 8.92 & 2.47 & - & - \\
\hline 1065B & $2.9 \mathrm{gh}$ & III & 3 & Krem & 8.67 & 2.29 & - & - \\
\hline $919 \mathrm{M}$ & $2.9 \mathrm{gh}$ & II & 1 & Beyaz & 9.45 & 2.25 & 23.79 & 0.99 \\
\hline $784 \mathrm{Se}$ & $3.0 \mathrm{gh}$ & III & 3 & Beyaz & 8.49 & 1.77 & 24.03 & 1.06 \\
\hline $812 \mathrm{Ku}$ & $3.1 \mathrm{fgh}$ & III & 4 & Beyaz & 8.73 & 2.53 & - & \\
\hline $927 \mathrm{M}$ & $3.1 \mathrm{fgh}$ & II & 4 & Gri & 9.29 & 2.73 & 23.58 & 0.99 \\
\hline $903 \mathrm{M}$ & $3.2 \mathrm{fgh}$ & II & 2 & Beyaz & 9.78 & 2.45 & - & - \\
\hline $1036 \mathrm{~K}$ & $3.3 \mathrm{fgh}$ & III & 2 & Gri & 10.69 & 1.72 & - & - \\
\hline 1095B & $3.3 \mathrm{fgh}$ & III & 4 & Beyaz & 8.88 & 2.19 & - & - \\
\hline $947 \mathrm{M}$ & $3.3 \mathrm{fgh}$ & III & 3 & Beyaz & 8.73 & 1.95 & - & - \\
\hline $841 \mathrm{Ku}$ & $3.4 \mathrm{fgh}$ & II & 3 & Gri & 8.45 & 1.79 & - & - \\
\hline $900 \mathrm{Bu}$ & $3.4 \mathrm{fgh}$ & III & 3 & Krem & 9.20 & 2.68 & - & - \\
\hline $1227 \mathrm{Na}$ & $3.4 \mathrm{fgh}$ & III & 3 & Beyaz & 9.28 & 2.36 & - & - \\
\hline $1137 \mathrm{Sa}$ & $3.5 \mathrm{fgh}$ & I & 0 & Gri & 9.23 & 2.35 & - & - \\
\hline 1071B & $3.6 \mathrm{fgh}$ & III & 3 & Krem & 8.78 & 1.85 & - & - \\
\hline $1024 \mathrm{~K}$ & $3.8 \mathrm{fgh}$ & II & 3 & Krem & 5.42 & 1.79 & - & - \\
\hline $962 \mathrm{M}$ & $3.8 \mathrm{fgh}$ & III & 3 & Gri & 8.77 & 1.83 & - & - \\
\hline $899 \mathrm{Bu}$ & $3.8 \mathrm{fgh}$ & II & 1 & Gri & 8.74 & 2.43 & - & - \\
\hline $1045 \mathrm{~K}$ & $3.9 \mathrm{fgh}$ & II & 3 & Gri & 9.61 & 1.73 & - & - \\
\hline $783 \mathrm{Se}$ & $4.1 \mathrm{fgh}$ & II & 4 & Gri & 8.59 & 2.8 & - & - \\
\hline $1216 \mathrm{Na}$ & $4.3 \mathrm{fgh}$ & II & 1 & Beyaz & 11.03 & 2.78 & - & - \\
\hline $1108 \mathrm{Sa}$ & $4.3 \mathrm{fgh}$ & II & 3 & Beyaz & 10.87 & 1.74 & - & - \\
\hline 770Sö & 4.6 efgh & II & 3 & Gri & 9.57 & 1.79 & - & - \\
\hline $785 \mathrm{Se}$ & $4.6 \mathrm{efgh}$ & II & 3 & Beyaz & 5.39 & 1.71 & - & - \\
\hline $781 \mathrm{Se}$ & 4.7 efgh & III & 3 & Beyaz & 9.52 & 1.7 & - & - \\
\hline $1027 \mathrm{~K}$ & 4.7 efgh & II & 2 & Beyaz & 8.17 & 1.81 & - & - \\
\hline $1248 \mathrm{Bu}$ & $4.8 \mathrm{efgh}$ & II & 3 & Beyaz & 9.36 & 2.18 & - & - \\
\hline $1005 \mathrm{Sr}$ & 4.9 efgh & II & 3 & Gri & 10.86 & 2.78 & - & - \\
\hline $961 \mathrm{M}$ & $5.3 \mathrm{efgh}$ & III & 2 & Beyaz & 10.32 & 2.33 & - & - \\
\hline $1252 \mathrm{Bu}$ & $5.5 \mathrm{efgh}$ & III & 3 & Beyaz & 10.19 & 2.87 & - & - \\
\hline 1091B & $5.8 \mathrm{efg}$ & III & 1 & Beyaz & 8.77 & 2.37 & - & - \\
\hline $828 \mathrm{Ku}$ & $6.5 \mathrm{def}$ & II & 3 & Gri & 9.34 & 2.29 & - & - \\
\hline 1049B & $7.8 \mathrm{de}$ & III & 3 & Beyaz & 8.78 & 1.96 & - & - \\
\hline $780 \mathrm{Se}$ & $7.9 \mathrm{de}$ & III & 3 & Gri & 9.21 & 1.8 & - & - \\
\hline $1207 \mathrm{Al}$ & $9.2 \mathrm{~cd}$ & II & 3 & Gri & 8.1 & 1.45 & - & - \\
\hline $861 C ̧$ & $11.5 \mathrm{c}$ & III & 3 & Gri & 8.01 & 1.73 & - & - \\
\hline 878Ç & $11.6 \mathrm{c}$ & III & 3 & Beyaz & 10.36 & 2.8 & - & - \\
\hline $998 \mathrm{Sr}$ & $15.3 \mathrm{~b}$ & II & 3 & Gri & 9.24 & 2.31 & 23.91 & 0.91 \\
\hline $1061 \mathrm{~B}$ & $18.7 \mathrm{a}$ & III & 3 & Beyaz & 9.52 & 1.51 & - & - \\
\hline
\end{tabular}

Not: Na Nazilli, Ku Kuşadası, Sö Söke, Ç Çal, Bu Buldan, Se Selçuk, M Menemen, K Kemalpaşa, B Bayındır, Sr Saruhanlı, Sa Salihli, Al Alaşehir.

a: Patojenite testinde her bir izolat için hesaplanan sürgün lezyonlarının değerlerini ifade etmektedir.

b: Ortalama değerler arasında istatistiki fark Duncan Çoklu Karşılaştırma Testine göre yapılmıştır. Sütun boyunca aynı harfi alan değerler arasında fark istatistiki olarak önemli değildir. 


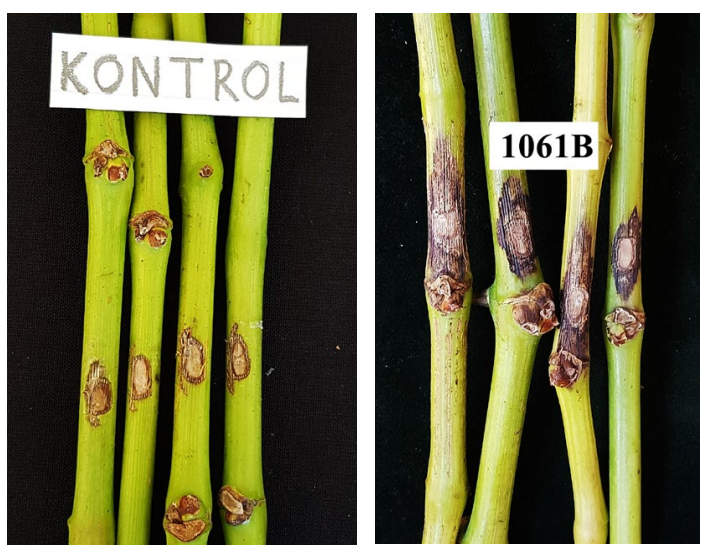

Şekil 4. Phomopsis viticola ile inokule edilen sürgünlerde inkübasyonun 15. gününde lezyon oluşumu.

\section{Tartışma ve Sonuç}

Bu çalışmada, Ege Bölgesinin bağ alanlarının yoğun olduğu Manisa, İzmir, Denizli ve Aydın illerinin örnekleme yapılan tüm ilçelerinde Ölükol Hastalığının belirtilerini gösteren asma bitkilerinin varlığına rastlanmıştır. Hastalıklı bitkilerde dip yapraklarda gelişen sarı klorotik lekelerin yanı sıra sürgün diplerinde nekroz ve derin çatlakların salkım sağlığını olumsuz etkilediği gözlemlenmiştir. Geçmişte Ege Bölgesinde Ölükol Hastalığının varlığ 1 birçok çalışmada rapor edilmiştir (Karaca ve Eroğlu, 1967; Özhendekçi, 1978; Erkan ve Larignom, 1998; Arı, 2000; Yıldırım, 2014). Oldukça geniş sürvey alanında yapılan bu çalışma ile ölü kol hastalığının günümüzde de Ege Bölgesinde bağ yetiştiriciliğinde önemini halen devam ettirdiği ortaya konmuştur. Nitekim Tarım ve Orman Bakanlığının yayınladığı teknik talimatlarda Türkiye'de Ölükol Hastalığı asmanın en önemli dört ana hastalığından biri olarak kabul edilmektedir (Anonim, 2011).

Ölükol belirtileri gösteren asmalardan alınan doku örneklerinden elde edilen 232 adet Phomopsis spp. izolatı arasında kültürel özellikleri arasında belli düzeylerde farklılıkların olduğu belirlenmiştir. İzolatların çoğunluğu (\% 69.39) hızlı gelişme gösterirken, sınırlı sayıda izolatta (15 adet) yavaş gelişme gözlemlenmiştir. Koloni rengi değerlendirmelerinde izolatların \% 35.77‘s beyaz, \% 59.05 'sı gri ve \% 5.17 açık krem renkte koloni oluşturmuştur. Phomopsis cinslerinin besi ortamında W (beyaz renkli koloni) ve G (gri renkli koloni) olmak üzere iki farklı renkte koloni oluşturduğu daha önceki çalışmalarda bildirilmiştir (Kanematsu ve ark., 1999; Kanematsu ve ark., 2000; Awan, 2017). Awan (2017), Ege Bölgesi bağ alanlarından izole edilen P. viticola izolatları arasında her iki koloni rengine sahip izolatlara rastlandığı ve $\mathrm{W}$ tipi koloniye sahip olanların gelişme hızı ve virülensliğinin $\mathrm{G}$ tipte olanlara göre daha düşük olduğunu bildirmiştir. Çalışmamızda beyaz ve açık krem renkli kolonileri olan izolatlar hızlı ve orta hızda koloni gelişim göstermişken, kolonileri gri renkte olan izolatlar \% 70.8 oranında hızlı gelişim göstermiştir. Ancak bu çalışmada izolatlarda oluşan beyaz ve gri koloni renkleriyle virülenslik şiddeti arasında herhangi bir farklı1ık saptanmamıştır. Bunun dışında çalışmada izolatlarda gözlemlenen koloni gelişim hızı, piknit oluşumu ile spor tipi ve büyüklükleri gibi diğer morfolojik özellikler ile virülenslik arasında bir ilişki kurulamamıştır. Tüm virülenslik gruplarında hemen hemen her morfolojik özellikte izolatlar yer almıştır.

Morfolojik olarak PCR negatif ve PCR pozitif izolatların arasında büyük bir farklılıklara rastlanmamıştır. $\mathrm{Bu}$ nedenle $P$. viticola'nın doğru tanımlanması için moleküler tanının yapılması gerekmektedir. Akgül ve ark. (2015), asma gövde fungal hastalıklar ile ilgili yaptıkları çalışmada yaklaşık 350 sürgün örneğinden sekiz farklı tür asma gövde fungal etmeni izole etmişlerdir. Çalışmada Diaporthe ampelina (P. viticola), etmeni krem renkte koloniler, alfa ve beta sporları ile tanımlamıştır.

İzolatların piknit oluşum değerlendirmesinde ise, izolatların \% 97.84' inda piknit oluşumu gözlemlenirken piknit yoğunluğunda farkl1lıklar saptanmıştır. Sadece 5 izolatta piknit oluşumu gözlemlenmemiştir.

Besi ortamında izolatlardan sadece 13 adeti alpha ve beta sporlardan her ikisini de oluştururken izolatların büyük çoğunluğunda (\% 94.39) sadece alpha konidi görülmüştür. Beyaz ve açık krem renkli olan izolatlarda alfa ve beta sporları görülmüş ve gelişme hızı ve büyüme çapı gri renkli kolonileri olan izolatlara göre daha az ve dar büyüme halkaları ile gelişme göstermiştir. $P$. viticola diğer Phomopsis 
türleri gibi piknidium içindeki $\alpha$ ve $\beta$ sporların oranı ve boyutları önemli ölçüde değişebilmektedir (Uecker, 1998; Sergeeva ve ark., 2003; Özben, 2011; Awan, 2017). Schilder ve ark. (2005), asma örnekleriden izole edilen $P$. viticola izolatların ortalama $\alpha$ sporların boyutlarının 9.8-12.6 $\times 3.1-4.5 \mu \mathrm{m}$ arasında olduğunu saptamışlar ve bu boyutların Mostert ve ark. (2001), ve Pearson ve Goheen (1994), çalışmalarından farklı olduğunu ve farklılığın nedeninin büyüme ortamındaki farklılıklar veya izolatlar arasındaki genetik farklılık olabileceğini ifade etmişlerdir. Çalışmamızda sırasıyla 8-11.04 $\mu \mathrm{m}$ x 1.7-2.8 $\mu \mathrm{m}$ boyutta alfa ve beta sporları saptanmış ve bu değerler Schilder ve ark. (2005), çalışmasında ifade edilenlere yakın olsa de genel olarak yine de farklı oldukları söylenebilir. Ayrıca Akgül ve ark. (2015), tarafindan Diaporthe ampelina ( $P$. viticola), etmeninin Alfa ve beta sporlarının ortalama boyutları sırasıyla $10.0 \times 2.4$ ve $22.5 \times 1.0$ olarak ölçülmüştür.

Çalışmamızda izole edilen 214 P. viticola izolatının End-Point PCR kiti kullanılarak moleküler tanısı başarılı bir şekilde gerçekleştirilmiştir. Türkiye'de geçmişte yapılan birçok çalışmada $P$. viticola'nın tanısı sadece morfolojik özelliklere bakılarak yapılmıştır (Karaca ve Eroğlu, 1967; Onoğur 1985; Çetinkaya ve Onoğur, 2006; Özben, 2011; Yıldırım, 2014). Phomopsis spp'nin moleküler tanıs1 DNA'nın farklı gen bölgelerinin polimeraz zincir reaksiyonları (PCR) ile çoğaltılması ve filogenetik analizler ile gerçekleştirilmiştir (van Niekerk ve ark., 2005; Santos ve ark., 2010; Udayanga ve ark., 2011 ve Gomes ve ark., 2013). Akgül ve ark. (2015), Türkiye'nin Ege Bölgesi İzmir ve Manisa İlleri bağ alanlarından sultaniye çekirdeksiz asmalardan elde edilen ölü kol izolatlarının kültürel özelliklerinin yanısıra ITS, TUB ve EF1- $\alpha$ gen bölgelerinin dizi analizleri ile tanı çalışmaları sonrasında ve $P$. viticola teleomorf D. ampelina ile ilişkilendirilmiştir. Awan (2017), 23 Phomopsis (Diaporthe) spp. izolatın, PCR da universal primerler kullanılarak elde edilen PCR ürünlerinin DNA dizilim analizi sonrasında $P$. viticola olduklarını saptamışlardır. Güngör Savaş, 2019 yıllında Ege Bölgesinde Manisa ilinin Şehzadeler, Salihli ve Akhisar ilçeleri ile Marmara Bölgesi Tekirdağ ilinden toplanan odun dokusu patojen izolatlarının ITS1 ve ITS4, Bt2a ve Bt2b primerler kullanılarak elde ettikleri PCR ürünlerinin DNA dizi analizleri sonucunda $P$. viticola'nın tanısı yapılmıştır.

Geçmişte $P$. viticola izolatlarının farklı asma çeşitlerinin yeşil sürgünlerin üzerinde patojenisite testi birçok araştırıcı tarafından yapılmış ve yapılan tüm çalışmalarda $P$. viticola'nın patojenik olduğu ve virülenslik açısından izolatlar arasında farklılıkların olduğu bildirilmiştir (Baumgartner ve ark., 2013; Urbez-Torres ve ark., 2013 ve Awna, 2017). Nitekim Türkiye'de yapılan bir çalışmada, y1llık Tarsus Beyazı asma çeşidini yeşil sürgünleri ile yapılan patojenisite testin sonucunda izolatlar arasında virülensliği yüksek izolatların yanısıra düşük olanların da varlığı bildirilmiştir (Awan, 2017). Bu çalışmada da sürgünlerde yapılan patojenisite testinde izolatların tümünde Ölükol simptomları gözlemlenmiş olup ve izolatlar arasında farklı virülenslik dereceleri saptanmıştır.

Sonuç olarak, bu çalışmada Ege Bölgesinde bağ alanlarında Ölükol belirtisi gösteren bitkilerden elde edilen izolatların büyük bir çoğunluğunun $P$. viticola olduğu ortaya konmuştur. Bu bulgular Ege Bölgesi bağ alanlarında Ölükol Hastalığından sorumlu ana patojenin $P$. viticola olduğunu göstermektedir. Asmalarda diğer Phomopsis türlerinin yanısıra farklı Diaporthe türlerinin de Ölükol Hastalığına yakın belirtiler verdiği daha önceki çalışmalarda belirtilmiştir. Ancak bu çalışma ile Ege Bölgesi bağ alanlarında diğer Phomopsis türlerinin ekonomik açıdan önemli olmadığı anlaşılmaktadır. Bu çalışmada gen dizilimi analizi yapılmamış olması nedeniyle $P$. viticola izolatlarının hangi teleomorf Diaporthe türü ile ilişkili olduğunu kesin olarak söylemek mümkün değildir. Ancak bölgede daha önce yapılan çalışmalarda $P$. viticola izolatları sıklıkla Diaporthe ampelina ile ilişkilendirilmiştir (Akgül ve ark., 2015; Awan, 2017). Bu raporlara göre çalışmada elde edilen izolatların D. ampelina olma olasıllığ1 oldukça yüksektir. Ancak bu durumun açıklığa kavuşturulması için izolatların DNA dizilim analizleri ile teleomorf tanılarının yapılması faydalı olacaktır. Bu çalışmanın sonuçları bölgede hastalıkla ilgili gelecekte yapılacak olan çalışmalara katkı sağlayacağı düşünülmektedir.

\section{Teşekkür}

$217 \mathrm{O} 293$ proje numarası ile bu çalışmayı destekleyen TÜBİTAK-TOVAG’a teşekkür ederiz. Bu çalışma doktora tezden elde edilmiştir. Bu çalışma yayın etiğine uymakta. Bu çalışmada etik kurul onayı gerektirmemektedir. Bu çalışmada yazarlar arasında herhangi bir potansiyel çıkar çatışması bulunmamaktadır. 


\section{Kaynakça}

Anonim. (2019a). Kilis Üzüm Raporu, T.C. İpekyolu Kalkınma Ajansı.

Anonim (2019b). Tarım Ürünleri Piyasaları. Tarımsal Ekonomi Politika Geliştirme Enstitüsü. https://arastirma.tarimorman.gov.tr/tepge. Erişim Tarihi: 11.03.2020.

Anonim. (2011). Zirai Mücadele Teknik Talimatları. Gıda, tarım ve hayvancılık bakanlığı, tarımsal araştırmalar ve politikalar genel müdürlüğ̈̈, 23-82.

Akgül, D. S., Savas, N. G., Teker, T., Keykubat, B., Mayorquin, J. S., \& Eskalen, A. (2015). Fungal trunk pathogens of Sultana Seedless vineyards in Aegean region of Turkey. Phytopathologia Mediterranea, 54(2), 380.

Ar1, M. E. (2000). A general approach for esca disease in the vineyards of Turkey. Phytopathologia Mediterranea, 39 (1), 35-37.

Awan, Q. N. (2017), Characterization of Phomopsis isolates causing phomopsis dieback of grapevine and their sensitivity against some fungicides and hot water treatments. (MSs), Çukurova Üniversity Institute of Natural and Applied Sciences Adana, Turkey.

Baumgartner, K., Fujiyoshi, P. T., Travadon, R., Castlebury, L. A., Wilcox, W. F., \& Rolshausen, P. E. (2013). Characterization of species of Diaporthe from wood cankers of grape in eastern North American vineyards. Plant Disease, 97(7), 912-920.

Çetinkaya, N., \& Onoğur, E. (2006). Organik yetiştiricilik yapılan yuvarlak çekirdeksiz üzüm bağlarında farklı gübreleme uygulamalarının külleme hastalığı gelişimi ve verime etkileri. Ege Üniv. Ziraat Fak. Derg., 43 (1), 33-44.

Erincik, O., Açıkgöz, S., \& Döken, M. T. (2018). Aydın ilinde cryphonectria parasitica'nın hypovirülent strainleri kullanılarak kestane kanseri hastalıgı ile biyolojik mücadele olanaklarının arastırlması ve uygulanması. TÜBİTAK, TOVAG 1140403 nolu Proje Bitirme Raporu. Ankara.

Erincik, Ö., Özdemir, Z., Durdu, Ö. F., Döken, M. T., \& Açıkgöz, S. (2011). Diversity and spatial distribution of vegetative compatibility types and mating types of Cryphonectria parasitica in the Aydın Mountains, Turkey. Eur J Plant Pathol, 129, 555-566,

Erkan, M., \& Larignom, P. (1998). Fungi associated with esca disease in grapevines in the Agean Region. Turk. Phytopath, 27, 2-3, 137-143.

Food and Agriculture Organization Of The United Nations (FAO). (2018). http://faostat.fao.org/site/535 Erişim Tarihi: 28.07.2020.

Gomes, R. R., Glienke, C., Videira, S. I. R., Lombard, L., Groenewald, J. Z., \& Crous, P. W. (2013). Diaporthe: a genus of endophytic, saprobic and plant pathogenic fungi. Persoonia, 31, 1-41.

Güngör Savaş, N. (2019). Asmalarda fungal odun doku hastalık komplekleslerinin tanılanması ve yönetimi. Uluslararası Multidisipliner Akademik Çalışmalar Sempozyumu, İzmir/Türkiye.

Hosseinalizadeh, S., Erincik, Ö., \& Açıkgöz, S. (2020). Screening of some plant pathogenic fungi for the presence of dsRNA mycoviruses. Bitki Koruma Bülteni / Plant Protection Bulletin, 60 (1), 57-62.

Kanematsu, S., Minaka, N., Kobayashi, T., Kudo, A., \& Ohtsu, Y. (2000). Molecular Phylogenetic Analysis of Ribosomal DNA Internal Transcribed Spacer Regions and Comparison of Fertility in Phomopsis Isolates from Fruit Trees. Journal of General Plant Pathology, 66(3), 191-201.

Kanematsu, S., Kobayashi, T., Kudo, A., \& Ohtsu, Y. (1999). Conidial Morphology, Pathogenicity and Culture Characteristics of Phomopsis Isolates from Peach, Japanese Pear and Apple in Japan. Japanese Journal of Phytopathology, 65(3), 264-273.

Karaca, İ., Eroğlu, G. (1967). Türkiye bağlarında yeni bir hastalık'ölü kol' üzerinde araştırmalar. Ege U. Z. Fak. Dergisi 4, (2) 28-35.

Merrin, S. J., Nair, N. G., \& Tarran, J. (1995). Variation in Phomopsis recorded on grapevine in Australia and its taxonomic and biological implications. Australasian Plant Pathology 24, 44-56.

Mostert, L., Crous, P. W., Kang, J-C., \& Phillips, A. J. L. (2001). Species of Phomopsis and a Libertella sp. occurring on grapevines with specific reference to South Africa: morphological, cultural, molecular and pathological characterization. Mycologia 93, 146-167.

Mostert, L. (2000). the characterization and control of Phomopsis cane and leaf spot on vine. (MSc), Science in Agriculture at the University of Stellenbosch, South Afrikaans. 
Niekerk, J. M., Groenewald, J. Z., Farr, D. F., Fourie, P. H., Halleen, F., \& Crous, P. W. (2005). Reassessment of Phomopsis species on grapevines. Australasian Plant Pathology, 34, 27-39.

Nita, M., Ellis, M. A., Wilson, L. L., \& Madden, L. V. (2006). Evaluation of a Disease Warning System for Phomopsis Cane and Leaf Spot of Grape: A Field Study. Plant Disease, 90-1239.

Onoğur, E., Kaçar, E., \& Çetinkaya, N. (1988). Untersuchungen über die Rolle der Phytoalexine bei der Resistenz von Weinrebe gegenüber Phomopsis viticola. J. Turk. Phytopath, 17(3), 143.

Özben, S. (2011). Ankara ili băg alanlarında görülen fungal hastalıkların ve yaygınlık oranlarının belirlenmesi. (YL), Ankara Üniversitesi Fen Bilimleri Enstitüsü Ankara, Türkiye.

Özhendekçi, N. (1978). Kocaeli, Sakarya ve İstanbul illerinde bağlarda Ölü kol hastalığını yapan etmen (Phomopsis viticola) üzerinde ön çalışmalar. Zirai Mücadele Araştırma Yıllı̆̆g Sayı:12.

Pearson, R. C., \& Goheen, C. (1994). Phomopsis cane and leaf spot. In: Hewitt WB, Pearson RC, eds. Compendium of grape diseases. St. Paul, Minnesota: APS Press, 17-18.

Poyraz, D., \& Onğur, E. (2011). Bağlarda Kav ve Petri Hastalıkları. Anadolu Journal of AARI 22 (2), 69-81.

Rawnsley, B. (2002). Phomosis taxon 1 on grapevine: pathogenicity and management. (PhD), University of Adelaide, Department of Applied snd Molecular Ecology Faculty of Sciences, Adelaide, South Australia.

Schilder, A. M. C., Erincik, O., Castlebury, L., Rossman, \& A., Ellis, M. A. (2005). Characterization of Phomopsis spp. Infecting Grapevines in the Great Lakes Region of North America. Plant Disease, 89, 755-762.

Sergeeva, V., Nair, N. G., BarchiaA, I., Priest, M., \& Spooner-Hart, R. (2003). Germination of $\beta$ conidia of Phomopsis viticola. Australasian Plant Pathology, 32, 105-107.

Udayanga, D.,Liu,X., McKenzie, E. H. C., Chukeatirote, E., Bahkali, A. H. A., \& Hyde, K.D. (2011). The genus Phomopsis: biology, applications, species concepts and names of common phytopathogens. Fungal Diversity 50, 189-225,

Uecker, F.A. (1998). A World list of Phomopsis names with notse on nomenclature, morphology and biology, Mycologia Memoir, 13, 1-231.

Úrbez-Torres, J. R., Peduto, F., Smith, R. J., \& Gubler, W. D. (2013). Phomopsis dieback: a grapevine trunk disease caused by Phomopsis viticola in California. Plant Disease, 97(12), 1571-1579.

Van Niekerk, J. M., Groenewald, J.Z., Farr, D.F., Fourie, P. H., Halleen, F., \& Crous, P. W. (2005). Reassessment of Phomopsis species on grapevine. Australasian Plant Pathology, 34, 27-39.

Yildırım, I. (2014). Influence of some food additive chemicals to Phomopsis viticola sacc. Review on Agriculture and Rural Development, 3 (1), 2063-4803. 